\title{
Moralities, Money and Extractive Capitalism
}

Venezuelans know the price of everything and the value of nothing

Venezuelan actor and intellectual Julio Motta, cited in Strønen and Wærness (2007)

Caracas, spring 2011: I was sitting on a tall bar chair in a little DVD and CD stall located in a small and worn-down basement shopping mall close to La Hoyada, in downtown Caracas. I was doing an interview with Ricardo, a family man in his 30s from 23 de Enero, and a newly elected vocero (spokesperson) for the communal council in his street. He was the owner of the stall, and I was interviewing him as passing customers stopped for a peek, to purchase something or for a chat. Ricardo had recently been elected vocero for the Committee for Ideology. At the meetings I had attended in his community, he was always trying to cut through the quarrels, urging people to come to their senses, stop fighting and rather think about the collective good. The community was in the midst of finalizing housing projects that would benefit around 20 families. This was a project that had been going on for a long time, causing a lot of rifts, quarrels and dirty maneuvers among the neighbors. Now, the money seemed to be on its way, and with some secret horse-trading and heated public arguments, the matter of who would be benefiting from it was settled. However, it had been a long process. Allegations of robbery, fraud and ulterior motives had stirred tempers and caused the consolidation of two factions in the community competing to gain control over the process. Ricardo was frustrated about his community and the way people behaved: 
When resources are given to us, the communal council in each parish has to be sincere, honest, right? We cannot get greedy when we see the money, because you know one thing, the money is the enemy, money cannot be viewed as raw (en bruto) because then the person becomes distracted or corrupted, just by the thought of taking a piece of this, right?

And that is already egoism, because you cannot ... one cannot think of this, but you have to think that it is for the community, because it belongs to the community as such and if a person is going to carry out a project and in the long run resources are diverted, then we are falling into the same trap as before, then we are not making a real effort to change.

The idea is that that resources are transferred for projects for the future, that no one skims off a bolivar because then we are doing ... I am talking from my point of view, if anyone skims off the minimum of a céntimo, then unfortunately everything is ruined. Why? Because then we are entering into corruption, and if I see that this person skimmed off a céntimo, then the other person also wants a céntimo and when everyone wants, then in the end of the day nothing is done.

With these comments, it was as if Ricardo attributed to money an uncanny ability to corrupt the person who sees it. Money is not to be seen "raw," he says: "If I see that this person skimmed off a céntimo, then the other person also wants a céntimo and when everyone wants, then in the end of the day nothing is done." Like the Coca Cola bottle that falls down in the middle of the Kalahari Desert in the film The Gods must be Crazy (Uys 1980), money has the ability of making everyone fall under its spell and eventually making everything fall apart.

Ricardo's choice of words was not unique. Often, people lamented how the seductive power of money was working against the Bolivarian process from within, engendering conflicts and corruption; promoting "individualism," egoism, greed and consumerism; and preventing a revolutionary consciousness from gaining foothold. These templates were talked of as the products of the country's capitalist history during the Fourth Republic, and how the implementation of neoliberalism by corrupt politicians from the 1980s onward had wrecked society from within.

By way of contrast, these historical experiences, and their imprint on the social and political body, were contra-posed to a new morality in the making: a revolutionary, socialist consciousness promoting collectivism, unity, integrity and solidarity. In this process, "Che's New Man" was to 
be born-the new man and woman that according to Che Guevara would develop through both material and moral incentives, as the revolution converted society as a whole "into a gigantic school" (Guevara 2003 [1965]:216).

In Venezuela, the concept "Che's New Man” was occasionally used by the more ideologically oriented: popular intellectuals, state officials and politicians, and Marxist-schooled activists. But discourses articulating "folk wisdom" also constantly reiterated that the Bolivarian process had to reverse capitalism's "vices" and engender a new social and political order, changing both the rules of politics and people's values and everyday life practices.

\section{Destructive Social Facts}

These ideas were often explicitly or implicitly tied to the template of oil; oil had since long ago generated a culture of voracious individualistic rentseeking among the elites and corrupted Venezuelan society. Now that oil wealth circulated in all spheres of society, the vices that it engendered were filtering down to ordinary people who behaved as if "my drop of oil" was finally up for grabs. Coronil has noted that: "As an extraordinary valuable commodity, it is hard for people to control [oil], particularly when it undergoes its most dramatic metamorphosis: when it becomes money" (Coronil 2008). As I delved deeper into Venezuelan history and social symbolism, I became increasingly fascinated by how the notions of capitalism, money and oil converged in templates and narratives of immorality and social destruction, bringing associations to Durkheim's "social facts." Oil wealth and extractive capitalism was viewed as having debased Venezuelan society since long ago through engendering particular sets of harmful norms, values and practices. If not countered and replaced with new moral economies and values, this legacy would destroy the Bolivarian process from within. The destructive power of oil was thus not only tied to its effects upon the political game and the economy, but also over people's hearts and minds.

\section{New Moral Economies}

Community politics was viewed as a key site for the emergence of new social and political relations through the crafting of new values and moralities. I use the concept of moralities in this context as a notion that "con- 
tain and express both discourse and practice" (Howell 1997:4). Moralities are not static templates, but rather founded on values that are susceptible to change through practices (ibid.). Analogously, practices considered conflictive, individualist, opportunist, scheming, and dishonest were frequently denounced, negotiated and mediated through a moral discourse emphasizing la falta de valores (lack of values) characterizing Venezuelan society.

I believe that it is paramount to understand the conflictual and contradictory nature of these processes not as a result of individual "virtues" or "deviances," or as evidence of the nation's "pathologies," but rather as the outcome of a series of historical, cultural, social and political processes. We need to capture how Venezuela's experience with oil-saturated capitalist-and later neoliberal-economic, political and social formations, were conceptualized within a moral and value-laden repertoire. In that frame of mind, we are better equipped to capture how contested practices, and the way these were conceptualized through discourses of moralities, constituted a focal point whereby the historical formation of Venezuelan state and society was placed in juxtaposition to the Bolivarian vision of a new social order.

\section{Neoliberalism and the Social}

Within academia, as well as the realms of policy-making, realpolitik, political activism and folk wisdom, the concept of neoliberalism is deployed in highly heterogeneous ways. In its orthodox economic sense, neoliberalism is often presented (by its proponents) merely as an economical-political restructuring of society whereby the role of the state is reduced in order to obtain a better, and supposedly socially more beneficial (at least in the long run), distribution of goods and services through an unhindered market. Scholarly criticism of neoliberalism does not only concern the kind of policies it promotes, and its frequently harsh social consequences in the form of increased poverty and inequality, but also the ways in which it works at an ideological level. As Gledhill notes:

What makes neoliberalism something that a classic liberal such as Adam Smith would have found as disturbing as Pope John Paul II does is its elision of the distinction between a market economy and a market society, to the point where the latter seems to engulf life itself. (Gledhill 2004:340, emphasis in original) 
Sandel, in his "Tanner Lecture on Human Values" delivered at Oxford in 1998, maintained that "one of the most powerful social and political tendencies of our time [is] the extension of markets and of market-oriented thinking to spheres of life once thought to lie behind their reach" (Sandel 1998:93). This blurring of boundaries between what belongs to the market and what doesn't is a powerful threat to society at large, he argues, as it blurs the boundaries of what can be bought and sold. Moreover, the increase of social and economic inequalities combined with the marketization of expanding spheres of human life undermines the republican ideal, dating back to Aristotle and Rousseau, of society as a common civic sphere. Tanner concludes his speech with the observations that there are certain "moral and civic goods that markets do not honor and money cannot buy" (Sandel 1998:122).

A consequence of the expansion of market thinking to the heart of civil life and public services is that citizenship-historically a notion capturing the relationship between rights and duties of the individual, the wider polity and the state- has been replaced with notions of consumer citizenship. As Scammel has noted: "It is no longer possible to cut the deck neatly between citizenship and civil duty, on the one side, and consumption, and self-interest, on the other" (McGregor 2002:20). The marketization of society has transformed the community and collective good into an obsolete imaginary object; each one of us is supposed to navigate within the array of market opportunities "offered" to us. A failure to do so is attributed to individual deficiencies, to a deviance from the free, self-creating individual that neoliberal ideology is founded upon.

\section{UNDERSTANDING LOCAL INTERPRETATIONS OF CAPITALISM}

There are significant differences between how market capitalism and neoliberalism have been absorbed in the Global North and in the Global South, and indeed between countries and regions in each sphere (Harvey 2005). These differences do not only concern how policies have been implemented, but also how reforms have interacted with the broader social, political, economic and cultural fabric. Anthropologists have, during the past decades, produced a broad array of ethnographic accounts documenting people's reactions to the high noon of capitalism in different parts of the world (e.g., see Comaroff and Comaroff 1987, 1999, 2001; Englund and Leach 2000; see also Ortner 2016). One of the most well-known accounts from Latin America about capitalism's 
effect on "traditional" societies is Michael Taussig's The Devil and Commodity Fetishism in South America (1980). Building upon Marxist theories of value as well as Marx's notion of commodity fetishism, he explores how the devil, in local folklore among African-Colombian plantation workers and Ayamara Bolivian tin miners, becomes an idiom through which the destructive effects of capitalism upon human and social relations are mediated. Through this account, Taussig argues that rather than seeing folkloric tales as irrational peasant believes, it is from the fringes of the capitalist economy that the enigma of capitalism can best be captured: "They provide us with insight into the irrational bias of our own economy and stereotype of homo oeconomicus" (Taussig 1977:475).

Capitalist critiques, with a Marxist underpinning, have always held sway over Latin American popular intellectuals and academic scholarship on Latin America alike, perhaps because the exploitative force of capitalism has always been so blatant. The ideological twins of Western modernity; the templates of liberal democracy and market capitalism, have been eagerly embraced by state builders at various historical junctures. However, following Polyani's insight that "markets thrive on formal equality combined with brutal inequalities in practice" (see also Sandel 1998; Hoffman and Centeno 2003; Weyland 2004; Fourcade and Healy 2007:293) there has often been a simmering resistance to, or at least ambivalence toward, "capitalism" among those who are excluded from, or unequally embraced by, its virtues (Gledhill 1995; Nugent 1996). This collusion between the economic paradigm of capitalism, the implementation of formal liberal democracy, and class politics is important in order to understand how the narrative of the Fourth Republic and its social, political and moral degeneration played out in the course of the Bolivarian process.

\section{Neoliberalism and the Social Body}

In Chap. 2, I outlined how the breakdown of the oil-fuelled developmentalist paradigm and the installment of neoliberal "shock treatment" caused a political and social havoc from the 1980s and forward. These processes spurred the deepening of social problems among those that were already most vulnerable in Venezuela. The incapacity of the market economy to incorporate the rapidly increasing informal urban population created a "surplus" population forced to scramble for its survival on the margins of society. Urban informal growth strained the barrios' already limited and inadequate infrastructure. The poor's inability to participate in the 
increasingly commodified "welfare market" relegated them to a state of permanent scarcity, insecurity and a sense of existential precariousness. The increasingly open hostility of the state, which by the end of the 1980s had abandoned its pretense of advocating for incorporating "the popular" into the state and nation body, relegated them to a condition of demeaning otherness. This perpetuated the sense of being cut out not only from a narrative of the nation-state itself, but also from the aspirations of a life project. At the same time, real wages declined and working conditions became worse, increasing the sense of exploitation and perpetual hardships.

As a result of these processes, people experienced not only a pulverization of the faith in the political system at large, but also a crumbling of the social fabric in the popular sector communities. People recount that their communities were previously experienced as quite meaningful and tightly knit social worlds in spite of abject poverty. They had their problems, and life was harsh indeed, but a sense of local security, collective local life and collective aspirations for the future still prevailed.

From the 1980s and onward the future was "called off." Social problems emerged on a large scale: violence and crime, the expansion of a violent drug economy, alcohol and substance abuse, an increased presence of weapons, life tragedies and family tragedies, a brutalization of collective spaces and subsequent retreat from communal life, acute needs, suffering and death. Life was experienced as a perpetual struggle to make ends meet, and significantly, a sense of being at war against each other as poverty became more aggravated and social needs became individualized. People experienced social trust and respect for others vanishing and informal social control mechanisms breaking down. In short, they experienced both a loss of meaning and a loss of a moral community and a collective future (see also Lander 2005).

It is important to understand these narratives as epistemological and ontological "truths" derived from people's real-life experiences. Not only do these referents undercut contemporary critique of capitalism's fragmentary, individualizing and violent effects, but they also help explain why Chávez's attacks on "capitalism," viewed by the Western press as oddities and derailings of a flamboyant populist, resonated with ordinary people. For them, "capitalism" epitomized a broader embodied understanding of social disintegration and anomalies that had permeated their individual lives and the social body throughout the past decades. 


\section{OIL SOCIETY}

Capitalism in Venezuela-both as a socio-economic model and as a social imaginary-cannot be properly understood unless we also capture how it has shaped and has been shaped by the country's oil wealth. Wealth circulation and wealth allocation in Venezuela, as well as social and political imaginaries, are born from this dialectic. Writing about oil wealth is always difficult. Oil constitutes a tangible substance, and at the same time, its representations are steeped in an enigmatic veil engendering imageries of certain pathological, social and political properties. As Coronil maintains, "oil does not do anything by itself," but it becomes an important factor shaping society "as it is transformed and used by people under given historical frameworks, specific historical situations and global economic context" (Coronil 2008).

Citizens in oil-rich countries are often presented as being captivated by the illusion of wealth abundance, displaying a series of behavioral traits such as sloth, chicanery and opulent consumption. Polish journalist Ryszard Kapuściński once noted that

oil creates the illusion of a completely free life, life without work, life for free ... the concept of oil expresses perfectly the enteral human dream of wealth achieved through lucky accident .... In this sense oil is a fairy tale and like every fairy tale a bit of a lie. (Watts 2004:213)

For his book Petromania (2009), Norwegian journalist Simon Sætre traveled to several of the world's oil countries in order to find out "what oil does to us." He coins the expression homo petrolicus: not a person with innate pathologies per se, but rather a person that adapts to the environment he or she is embedded in, following certain behavioral patterns caused by the centrality of oil wealth in public life.

The notion that oil wealth engenders particular social dynamics is a familiar one (Apter 1993; Karl 1997, 1999; Watts 1999). However, I posit that it is paramount to discern exactly how socially embedded "oil cultures" are articulated in everyday life practices, ideas of personhood and state-society relations at particular historical conjunctures. Thus, through exploring particular cultural idioms associated with money and oil wealth, such as consumption, individualism, corruption, egoism, values and greed, we may achieve a deeper understanding of the contested cultural qualities that the particular Venezuelan experience of oil-fuelled capitalism has engendered. 


\section{Conspicuous Consumption in Venezuela}

Cash is king in Venezuela. La plata, los reales, los billetes, however you call it, money gives you status, money gives you friends, money gives you power and not least, money gives you women.

For the rich: the opulent mansions and haciendas in Venezuela, their houses in Miami and the Dominican Republic, the SUVs, the surgically enhanced trophy wife or girlfriend, the upscale restaurants and clubs, the farandula (celebrity parties), the vacations to luxurious destinations, the jewelry, the designer clothes, the hair, the nails, the makeup, the maids and nannies.

For the middle classes: the constant struggle to move upward through symbolic consumption mimicking upper-class lifestyles as best they can. The commodification of the female body. The obsession with Western (read: US) consumer objects, clothes and habits, and the constant talk about what they have bought and where they bought it (preferably outside Venezuela). The flaunting show-off of conspicuous consumption.

For the "ordinary people" in the barrios: the Blackberry, the imported whiskey, the breast implants (or girlfriend with breast implants), the ceramic tile floors, the vacation to Isla Margarita (with tax-free shopping), the designer bags, branded clothes, the motorbike and so on. I have known women who spent an entire month's wage on a Louis Vuitton bag, and men who spent one-fourth of a month's rent on a bottle of whiskey. I have known a lot of people who spent at least two months of their minimum wage on a smart phone.

Guy Debord wrote: "the Spectacle is the other side of money; it is the general abstract equivalent of all commodities" (Debord 1967:1). The trips to shopping malls on the weekend: the opulent, glitzy shopping malls converted by rich and poor alike into something akin to a shrine: its shiny galleries, silent escalators and greasy, over-crowded fast-food courts. The malls have become the site of a bizarre self-conscious ritual, a site for confirming the atomized, yet collective triumph of modernity. The replica of the Statue of Liberty, four-stories tall, in the center of the El Recreo mall, in Central Caracas. Fervent little girls and boys enter the gates to consumer heaven, while a man carries his super-mega combo order of Kentucky Fried Chicken over to his family's plastic table as if he were carrying a tray of the finest oysters and champagne. 


\section{The Boom}

These were the years before the economic crisis set in, still the years of the vaca gorda (fat cow), when Venezuela's BNP was still pointing upward, inflation was still manageable and consumer products were readily available. Yet, the disparity between wages and consumption puzzled me; it didn't make sense. Money seemed to be everywhere, flowing from hand to hand, endless streams of transactions, deals, favors, trickeries, rebusques (inventive ways of generating extra income). Venezuelans were amazed themselves: at Christmas time everyone spoke about how crowded the streets were, how the consumption rates had hit the roof, how certain sought-after items (especially name-brand children's toys) were out of stock across Caracas. At every Easter and Christmas holiday, tickets for buses, boats and planes were sold out for practically all destinations and people would comment: "They say that things are going bad here, yet everyone is going on vacations." People in the barrios talked about how the streets had become more and more congested because of car sales hitting the roof, of how increasing numbers of barrio women had gotten their boobs and buttocks done, ${ }^{1}$ of how "everyone" had a Blackberry (though many didn't have money to use it) and not least, how people were now being killed in the street for their smart phones. Despite a collective acknowledgement of how the alluring symbols of wealth posed a threat to the social fabric, the golden calf continued to be worshipped nonetheless. The spectacle of consumption was so powerful that one could start to wonder if there was any poverty left, or if those who didn't partake in the fiesta were just too principled, or simply not cunning enough. Money seemed to have an uncanny yet ubiquitous existence in the midst of a political process that not only sought to sow the idea of creating a society based upon socialist notions of the collective good, but which also denounced consumption as one of the evils of capitalism.

\section{The Ambivalence of Wealth}

The ambivalence of wealth is a thin red line running through Venezuelan modern history. Coronil has written about how Venezuela's black gold became vested with magical, yet destructive powers, vowing to lead its citizens toward the promised land of development, modernity and prosperity - a siren's song that never materialized (Coronil 1997). Indeed, the symbolic representations of wealth, status and money in Venezuela cannot 
be understood separately from the manner in which oil wealth has circulated both as an imagery and as a source to great wealth throughout the social and political body. It divided the population between those who consumed and those who stood on the outside looking in on the consumer spectacle, ascribing power to those who could possess the conspicuous symbols of wealth, and creating both desires and resentments among those who could not.

Many authors have pointed to the emergence of a culture of conspicuous consumption developing in Venezuela as oil rent started to circulate in society in the first half of the twentieth century (Ewell 1984; Hillman 1994; Coronil 1997; Tinker Salas 2009). This was not only offset by the increasing influx of North American and European consumer goods, but also by an increasing volume of North American media sources such as TV, print and newspapers (Ewell 1984:134-144) as well as by the presence of North American oil companies (Tinker Salas 2009). As we discussed in Chap. 2, the latter not only implied the general formation of an imagery of national progress and modernity via oil-financed development actively conjured by the oil companies (Tinker Salas 2009). It also implied an increasing contact between segments of the Venezuelan population and North American residents - oil managers, oil workers and their families - whereby North American consumer values and class symbolisms were absorbed by a rapidly growing population in search of a national identity (Tinker Salas 2009). These factors created a process of cultural reconfiguration whereby the national imageries of class identities as well as modernity, development and progress were associated with the ability to consume "US style."

The first government of Carlos Andrés Pérez, in the 1970s, deepened and added new dimensions to this cultural imagery. Vowing to propel the country into first-class status financed by the booming oil wealth, the government flushed enormous amounts of money throughout the system. Ruthless corruption and rent-seeking made the upper classes perversely rich, "flaunting their loot" (Coronil 1997:360) in public. As Duno (1975) worded it: "Clothing, automobiles, jewelry, mansions, trips, yachts, more and better clothing, automobiles, jewelry, mansions, trips, yachts" (Duno 1975:58, cited in Coronil 1997:337). Middle-class Venezuelans went on shopping trips to Miami for the weekend, giving birth to the idiom está barato, dáme dos (it is cheap, give me two). Symbolically, PDVSA employees often flew with the company's planes for their leisure trips. Venezuela 
became known internationally as Venezuela Saudita. An article written in 1978 by Caracas correspondent Peter Arnett in the US newspaper News and Courier reads:

Buy a 3-foot tall Salazar of French champagne from your local supermarket, price 459 USD including the ice to chill it. Transport your purchase in a USD 45,000 white Mercedes Benz sedan from any one of a dozen nearby dealer. And discreetly drink it with your secretary in any one of a dozen private clubs, membership fees up to USD 100,000. All these items are available and have ready buyers in Caracas, the capital of Venezuela, where cascading oil wealth has given new meaning to the cliché "boom town." (Arnett 1978)

The article cites a US embassy official who "fretted" that "he felt more underprivileged here than any other place in the world," and made reference to the daily Pan Am 747 flight called the "Disneyland Shuttle" between Caracas and Miami that returns "each evening with exhausted big spenders laden with purchases." Referring to the nouveau rich oil-spurred spending in Saudi Arabia, the journalist interviews a Swiss hotel manager who has worked in Saudi Arabia, who says that "the Venezuelan are much more light-hearted about spending money than the Arabs ... they enjoy it more I think." The article also mentions the poor who observe the downtown spending spree from the shantytowns hills, quoting a US government report which estimates that one-third of the country's population is ill-fed, ill-clothed, ill-housed and ill-schooled. However, the author notes that the social unrest found in other Latin American countries with great economic inequalities seems to be lacking. He quotes a Caracas journalist saying that: "They think they'll get money too. It seems so near" (Arnett 1978).

As we now know, this boom only lasted four more years. By then, the national imagery of material culture had been saturated with conspicuous consumption US style, a trait that continued to shape national identities also in the decades to come. Thus, paradoxically, while during this epoch the government of Carlos Andrés Pérez pledged to modernize the country and bring it on the path to prosperity and development-in itself a collective project of state building - an increasingly powerful individualized notion of modernity was perpetuated, that of wealth, power and success displayed by crude consumption. 


\title{
The Power of Conspicuous Consumption
}

As should be clear by now, I am not concerned with consumption per se. Rather, my interest is to unearth what discourses about consumption can reveal about how popular sector activists conceptualized the Bolivarian process, and the ways in which the template of consumerism gained salience in discourses about capitalism's effect on Venezuelan society. As Slater (1997) puts it: "To state the obvious, consumer culture is capitalist culture" (Slater 1997:26). Consumer culture was born from capitalist arrangements of labor, capital and production, and social critique against consumerism is as old as capitalism itself. Alexis de Tocqueville, visiting the young nation of the USA in 1831, observed that:

\begin{abstract}
Among democratic nations, men easily attain a certain equality of condition, but they can never attain as much as they desire. It perpetually retires from before them, yet without hiding itself from their sight, and in retiring draws them on. At every moment they think that they are about to grasp it; it escapes at every moment from their hold. They are near enough to see its charm, but too far off to enjoy them; and before they have fully tasted its delights, they die. (Alexis de Tocqueville 1904:624-625, cited in Mullins 2011:1)
\end{abstract}

In 1899, Veblen introduced the now well-known concept of conspicuous consumption, arguing that capitalist consumption was just as socially destructive as the capitalist production process itself (Fourcade and Healy 2007:291). However, while a culture of "consumerism" as such is an old phenomenon, global mass consumption, in its contemporary form, is often seen as a key feature of late-twentieth-century globalization in the form of ever-expanding flows of cultural mass imageries and mass commodities (see Slater 1997 for a thorough analysis). There is a broad body of anthropological literature dealing with novel ways of understanding the role and meaning of consumption in the contemporary world (Appadurai 1988; Friedman 1994; Douglas and Isherwood 1996; Miles 1998; Jackson 1999, 2004; Walsh 2003; Graeber 2011). As these analyses emphasize, global imageries of consumption are codified, transformed and absorbed in numerous ways in different cultural contexts. However, in its essence, the dominant imagery of consumption is shaped by a lifestyle that is intrinsically interlinked with broader notions of modernity emanating from the Global North. As Slater notes:

Consumer culture is in important respects the culture of the modern westcertainly central to the meaningful practice of everyday life in the modern 
world; and it is more generally bound up with central values, practices and institutions which define western modernity, such as choice, individualism and market relations. (Slater 1997:8)

Intersecting with broader templates of modernity such as liberalism, consumption is projected through a densely packed message of freedom epitomized by the concept of consumer sovereignty (Slater 1997:27). However, a broad body of work across disciplinary fields has dissected how the emancipatory message written into the imagery of consumption (freedom is to shop the identity of your choosing!) constitutes a very twisted or limited liberty, or liberty only for the few.

Paradoxically, the pressure to consume may be weighing in more heavily on those who do not have the capacity to consume (Miles 1998:151). Gledhill has put forward a similar perspective, arguing that "the measurement of social worth in terms of consumption and marketed 'lifestyle' symbols penetrates deeply even into the lives of the world's poorest citizens" (Gledhill 2004:340). No wonder then, that consumption often takes on a daydreaming quality; it becomes a way of imagining and fantasizing about the unattainable (Miles 1998:151).

These perspectives are important to capture, because they remind us that the poor are as equally prone to consume imageries of commodified lifestyles as the rich, creating an economy of desires and wants that intersects with a broader repertoire of power and domination, poverty and exclusion, identity formation, compliance and resistance. In Venezuela, as we learned above, the popular sectors were, throughout the twentieth century, relegated to the place of spectators witnessing their better-off fellow countrymen and women flaunt a lifestyle and level of consumption that was far beyond their reach. Indeed, during el Caracazo, it was not only food and household items that were looted; it was also TV-sets and refrigerators. As many of my informants said: "For a long time poor people had been forced to watch consumer propaganda touting what they should have. During el Caracazo some people used to opportunity to seize these things." The desire to consume had been "democratized" across society, but only a small part of the population had been able to partake in the fiesta. However, consumption took on a dark meaning for the popular sector, as expressed through the often-said truism "here will kill each other for a pair of shoes." The phrase originated in the 1980s, when the social hype around the Nike Escape models apparently led to a string of robberies and even murders. Being a tragic illustration of the localized outcomes 
of globalized messages about modern identities, the phrase "here we kill each other for a pair of shoes" remained in the popular social imagery, confirming the power of commodities in the construction of Venezuelan social identities.

\section{Consumption in the Age of Chavismo}

Consumption boomed under the Chávez government. Private per capita consumption grew more than 50 percent between 1998 and 2012. In 2013, Venezuela had 150 shopping malls for a country of almost 29 million inhabitants. In contrast, Argentina, with 40 million inhabitants had 19 malls (Informe21 2013) Throughout the Chavez period, purchasing power among the popular sectors increased significantly because of a combination of several factors: social spending targeting poor social groups, increased wages, a new oil boom and public policies creating expanded economic activities and, in turn, increased employment opportunities and circulation of capital. Due to the altered class profile of the state apparatus, more people from the popular sectors were able to access public sector employment. And with new political constellations, new public policies, and a new influx of oil resources, new channels to tap into public resources, through clientelism or corruption, were opened for new sectors of the population. Put together, these factors increased the purchasing power for people in the lower end of the socio-economic scale, and enabled them to consume beyond the level of "mere survival" as they were historically accustomed to. Now, they could also partake in symbolic consumption, and an increasing number of people did so, even if it often cost them hardship and sacrifice.

\section{Buying ON A Whim}

Many Venezuelans perceive themselves as heedless, senseless spenders, throwing out money, "here today, gone tomorrow," so thoroughly couched into a consumerist culture that they spend even if they don't need it and even if they cannot afford it. I discussed this one night with David, a young community activist, as we were sitting in his rooftop terrace overlooking the glittering lights across the valley of 23 de Enero:

DAVID: Here in Venezuela we are, we are quite consumistas, Venezuela has distinguished herself as one of the countries that 
consumes the most, so you can say that we are consumerists, we sometimes buy unnecessary things that we don't want or we don't need (...). Here we are practically living off imports, practically everything is imported, and now we are more consumerist, we buy ... every day we buy something.

ISELIN: And where does it come from, this need to buy something?

DAVID: It is not a need, sometimes it can be a need, depending on the point of view, but sometimes it is just a capricho (a whim) for having it. Here in Venezuela we have always lived, well, we still live something that is modernism, to give you an example, if I don't have this cap from a fashion brand, I don't feel well. And today, within society and above all in the barrios where you see this the most, among the youngsters, that if a youngster doesn't have clothes from a fashion brand they are not accepted by their groups and friends. That is where the mother also fails, because sometimes the mother abstains from buying necessary things for the home in order to buy unnecessary things for her children. So that is a problem that we also need to attack in today's youth and another thing as well, that today there are too many murders, for a telephone of a fashion brand, for a (inaudible) of a fashion brand, if we don't have purchasing power, for a capricho, we kill another person.

ISELIN: And from where and when do you think that this culture in Venezuela has come from?

DAVID: This is coming from decades ago, decades, decades, decades, that has been imprinted here by previous governments, as far as I know since Gómez and up till now ... the majority of the governments since then have been ... we have been invaded and acquired by capitalism, which is what we are fighting against today, and we are achieving this goal. Here, all the other governments have depended upon capitalism, we have been dominated by capitalism and today they are cataloguing the president as bad because he doesn't want to let himself be dominated by capitalism. We are neither going to let ourselves be dominated by capitalism because we have already woken up and saw reality, we woke up from this dream that had (inaudible) us ... now we are in a social dream, socialist, of justice and peace. 
Note that David attributes this cultural proclivity to spending to "modernism," which he directly associates with having name-brand clothes. Albeit a seemingly casual choice of words, it illustrates how modernity and symbols of global mass consumption were tied together in the popular imagery. David, who was pursuing a university degree in public administration, and who also had attended several courses in popular education, went on to immediately identify capitalism as the "culprit" for this national trait. This formulation illustrates how the template of "capitalism" within the Bolivarian discourse refers to a particular socio-cultural paradigm that the country has lived by for the greater part of the twentieth century. As he pointed out, Chávez was perceived as the first president who resisted this model of domination, setting Venezuelans on a new path toward social justice and peace-and at a confrontational path with the patrons of capitalist modernity.

\section{CONSUMERISM FROM WiTHIN}

The alluring power of conspicuous consumption constituted a source of deep preoccupation for many community activists. It was perceived as a form of "false consciousness" that made the popular sectors, now with a slightly better purchasing power, seek refuge in dreams of middle-class consumption and commodified Western identities instead of gaining consciousness about the cultural and political battle that the Bolivarian process constituted. Oscar, whom we recognize from the ordeal with the Community Hospital (CDI) in Chap. 5, was a particularly concerned interlocutor of this view. As a stern believer in poder popular and in the imperative of emancipation from cultural imperialism, he observed with great concern how people around him were drawn to dreams and practices of consumption. In one interview, he framed it this way:

OSCAR: Look, I will give you an example that concerns me and my daughter, I call her mamita, she is 10 years old. And we go for a walk in the park, or we are strolling, and she says to me, "Dad, I want to go to the shopping mall, the El Sambil, El Recreo." And I say to her: "But why will we go there?" My sister says that one goes there to glue your snot on the window displays of those large shopping malls ... those large shopping malls that are now all over the large cities like Caracas, Valencia, Maracaibo, Barquisimeto. So look, my daughter asks me to go there and these are some of the contradictions. 
And as she is a little girl, 10 years old, and I say to her but coño mamita, what are we going there for? "Well, to eat, to look." "But what are we going to look at?"

So having a shopping mall over there is to awake in her all this consumerism ... of buying this, of buying clothes, I ... I am a militant, I am a militant of revolutionary ideas, and these contradictions that I am hearing daily with my daughters, with my nieces and nephews, with my family, this is a debate that is going on daily ... and what do we do if where she is studying, in this school or in this sector where she lives sees these [values], what do we do? Because I cannot impose my ideas on her, rather, this is a constant process with her, to debate, to make her see the new values, or the values that I have (...).

Oscar was part of an old boy's colectivo in 23 de Enero, which for decades has been central in organizing cultural, sportive and social events in the community. They set themselves apart from many other colectivos in the community by their explicit non-militant style. Also, they were hesitant to tie themselves too closely to the new arenas for popular participation endorsed by the government. Rather, they considered popular struggle as essentially a process of bottom-up emancipation from both cultural and political modes of dominance and power. Consequently, Oscar and his comrades were deeply worried about many of the "vices" that continued to thrive within the Bolivarian movement, and the obstacles this posed for continuing political struggle beyond having a sympathetic government in power. He saw ideologies of consumptions as one of the most worrying signs of the limitations to the Bolivarian revolution as a process of deep socio-cultural change:

What can we do if there is this constant; the television, the internet, the mobile telephone in fashion. I mean, here people are saying that this is the country with the largest acquisition of new mobile telephones (smart phones) and in the communities, you get shocked how this is instilled in our young women, in your children, that the Christmas presents, from the Jesus Child ${ }^{2}$ in quotation marks, the arrival of these gifts from Christmas are telephones, they are giving a Blackberry to a child of seven, eight years .... What do we do then?

So look how society, how these big men have us subdued ... and they still have total dominance, that is without a doubt ... and besides, this is 
also one of the contradictions within our communities, in these processes of struggle that the communal councils are engaged in, that are taking place in the different community organizations, in sports, in culture, this debate or this diffusion of new ideas that is taking place. This is daily work, constant, at every hour...

Oscar's words are representative of how many people would conceptualize the paradox between the powerful template of consumption within the popular sectors and the simultaneous drive toward fomenting a new consciousness that was taking place in a variety of arenas. He found it puzzling and disturbing that many poor people seemed to prioritize buying consumer goods, at any cost, and that children were being pushed into a consumer culture through all media channels, supported by parents who failed to gain consciousness themselves. Indeed, a major concern of many activists was, above all, for young people, who were continuously induced into believing that "anything foreign" was way better than anything Venezuelan. All the brands that children and youths' culture revolved around were foreign: McDonalds, Kentucky Fried Chicken, Pizza Hut, Disney, Hello Kitty, Monster High, Hollywood blockbusters, Blackberry, Apple, Nike, Ralph Lauren, the list is endless.

The subject was also brought up in a conversation with Marta, a woman in her 30s originally of humble origins but now an accomplished singer. Over a cup of coffee by her mother's dining table in one of the low-rise apartment blocks in 23 de Enero, she spelled it out like this:

What is the most problematic about it? Ideologically we are still, we could say that the revolution is still in between the Fourth and the Fifth Republic ... the masses, el pueblo has really not imprinted, formed, what is socialism, this is why we are still living in the midst of capitalism. Chavismo, one of its principal traits I would say, is this love for the patria, the need for justice, that is why eight millions and something have voted for Chávez, because of this sense of nationalism that we had completely lost ... before the February $4,1992,{ }^{3}$ there wasn't this sense of patria, of nation .... Chavismo has this element which is what the esqualidos don't have, it doesn't interest them ... but what happens?

I am talking about the ideological element, the fight against consumerism, because certainly we have been able to break through these things and created a sense of patria, of national identification, of pride of being Venezuelan, of recognition, about what it means to be Bolivarian, where are we coming from, where are our roots, but still there are elements that are 
imprinted upon us, above all from the great enemy, what we have there in front of us, the media, Hollywood, we are trying to recuperate our national identity, but it is really difficult, really difficult, because our children still have Disney Channel—and I don't mean that Disney Channel is completely bad, but the problem is that we haven't managed, even with the educational processes at school, with the Canaimita, ${ }^{4}$ to make what is ours, our customs, our traditions, attractive to the younger generation...

Marta's way of expressing herself illustrates how the template of consumerism was tied to depreciating all things Venezuelan, a form of cultural imperialism undercutting the struggle for Third World political emancipation. Therefore, it was an important symbol of anti-consumerist nationalism when Chávez, in 2009, launched Venezuela's first domestically produced mobile telephone, the Vergatario, ${ }^{5}$ costing approximately 15 dollars. This was seen as an important confrontation with the power of cultural imperialism in Venezuela, and the telephone indeed quickly sold out, strategically launched by Chávez on live TV just before Mother's Day.

\section{SAMBIL SOCIETY}

A clearer picture is now emerging of how "consumerism" within Bolivarian discourse implied a broader set of signifiers describing Venezuelan history as a colonialized, transculturalized and socially segregated country. Consumerism became codified as the opposite of a people's history of Venezuela, of nationalist symbols, autochthonous traditions and national dignity. It was the child of the hegemonic globalization of the imagery of mass modernity "US style." Below is a text that eloquently captures this multi-layered interpretation of what consumerism represents, bringing out very clearly how it is socially and culturally codified within the current process of deep political polarization. The text, written as a poem and titled "What does it mean to be from Sambil society?" is a reference to the shopping mall chain Sambil, owned by the Venezuelan Cohen family, and probably the most potent symbol of consumer culture in Venezuela. Sambil Caracas is the third largest shopping mall in Venezuela. (The largest ones are in Isla Margarita and Maracay, which are among the largest in Latin America.) There are seven Sambil malls across Venezuela, in addition to one in Santo Domingo, the capital of the Dominican Republic, one in Curaçao, and one in Madrid (Sambil 2017).

Eighty thousand people a day visit Centro Comercial Sambil Chacao, in the center-east of Caracas (Informe21: 2013) It features two movie 
theaters, with a total of ten screens, a rooftop amusement park, a concert arena, a bowling alley, an arcade, a small aquarium and several food courts, with both international and national fast-food kiosks. It sells a range of international luxury brands, and has spin-off initiatives, such as a beauty contest and its own magazine. The chain also organizes group weddings in the month of February (cashing in on Valentine's Day) as a way to "demonstrate its compromise with the Venezuelan society" and in order to "promote and consolidate moral values in the Venezuelan society" (Notiactual 2011, author's translation from Spanish). Sambil arranges fashion shows, holds cooking classes for housewives, sponsors schools and sport facilities, organizes fundraising events and aerobic classes.

I am mentioning these details to underline that Sambil is more than a mall in Venezuela; it is a cultural symbol. The exact origin of the phrase Sociedad Sambil (Sambil Society, alluding to civil society) is uncertain, but it was famously used by the now-deceased popular revolutionary leader Lina Ron, founder and president of the party Unión Popular Venezolana (UPV). This twist of words elegantly captures how Sambil has come to epitomize a lifestyle, an attitude and an imagined class community. An article was later posted on the pro-government activist website www. apporea.org, entitled "What does it mean to be from Sambil society?" (Silva 2005). I will quote it in full here, because its extremely rich cultural references illustrates how templates of consumption, class and politics play into the deeper cultural-political struggles taking place between contrasting and contradictory worldviews.

What does it mean to be from the Sambil Society?

It is to live for consumption and not to consume in order to live, that is, to pass by your house and live in Sambil, not to live in your house and pass by Sambil.

It is to be an innocent victim of the dictatorship of the media of incommunication (sic), which from childhood on teaches one to live from appearance and not from essence.

It is to ridicule social sensibility that people with fortunes feel towards "the wretched of the earth" (Frantz Fanon).

It is to talk negatively about Venezuela and her people while drinking whisky in a bar in Las Mercedes (and the most fortunate ones in London), and when they meet for a business lunch in Altamira (idem in Paris).

It is to blame the Venezuelan people suffering in poverty for being lazy and irresponsible when it is these people who produce goods and riches for those parasites and for the gringo empire that they admire so deeply. 
It is to prefer to read Seventeen magazine instead of a book about Venezuelan history.

It is to know all the gossip from the parties in high society and beauty contests, and to ignore the socio-historical formation of Venezuela as a nation.

It is to discriminate against someone who doesn't have a luxury car or brand clothes like they have.

It is to imitate foreign fashion promoted on television, and to despise as monkeys and marginals the creole traditions and customs.

It is to dress the mind with T-shirts of Backstreet Boys and Britney Spears, and to look ugly upon those who dress their body in T-shirts of Ali Primera and Simón Bolívar. In a few words, it is to speak Spanish and think in English.

It is to feel pain for the dead North Americans in the World Trade Center in New York, and not feel anything for our dead Latino brothers in the Chorillos neighborhood when the United States invaded Panama.

It is to criticize with "squalid" hysteria the destruction of the statue of Christopher Columbus as an act of the marginal hordes of the circles of terror, and not to say anything about the civic pacific pull down of the statue of Cacique Guacaipuro in Los Teques when they did the guarimbas. ${ }^{6}$

It is to settle with being the pupil of a big high school when one should be a student at the university, and to graduate in order to serve an exploiter with the purpose of becoming like him, without caring about whether his work harms or benefits the people who paid for the existence of the very university.

It is to make tremendous fuss for knowing that there are students who don't eat at McDonald's or cannot pay for books, which is why they propose that each human right (like the right to education, to life or to freedom of expression) should be paid by those who have the most, and make it available at a low cost to the poor students (and not give it for free ... zero paternalism for the tierrúos (dirty poor) according to papa's boys), all based on a socio-economic study that converts the human rights of all (which should be free!) into a privilege for the few (who can pay).

It is to be an adulador rastacuero (sycophant ass-kisser) to a decadent and opportunist aristocrat professor, and to join him in scorning other members of the university community for their academic conditions, their social origin and their racial characteristics.

It is to call themselves civil society when they protest, and to call the poor hordes and mobs when they do the same.

It is to protest comfortably from their luxurious balcony putting on a CD with pot-banging ${ }^{7}$ to not get their delicate skin sweaty.

It is to be in favor of Chávez if he had been white and with blue eyes, and had talked in an abstract and technical language in order to be a hypocrite like them, instead of making objective and constructive criticism. 
It is to die from hunger in a shack on the shantytown hills, while thinking and wanting to be like them!!!!

In this text, Sambil Society takes on multiple meanings: of class resentments, of anti-nationalism, of lack of sense of patria and sense of social consciousness, of adulation for anything foreign, anything with superficial status, anything that represents the opposite of the values that the Bolivarian process - through its ideological thirdworldism outlook and class rooting - represents. Sambil Society implies to be a snob and a hypocrite. The very term "Sambil Society" refers to the ways in which, as is also described in the poem, the middle and upper classes call themselves civil society, whereas Chavista supporters are referred to as hordes and mobs. This is a point that is often underscored by Chavistas because, to them, it illustrates the global dimension of Venezuelan class conflicts; they interpret "civil society" as an ideological concept embracing a particular socio-economic group of global citizens (see also Chatterjee 2004 for an analysis of its historical origins and its colonial adaption). From the point of view of the popular sectors, the concept "civil society" is monopolized by the opposition and actively used as a worldwide marketing strategy in order to gain support for its cause, legitimizing oppositional and middleclass political agency while negating popular and pro-government agency.

It is however important to note that Sambil Society is not merely ascribed to class. Rather, the last line, "It is to die from hunger in a shack on the shantytown hills, while thinking and acting like them!" refers to poor people who try to associate with middle-class culture through consumption. They are often colloquially referred to as sifrinos. Bourdieu teased out the ways in which class mobility is conditioned by habitus-a lower-class person can aspire to social mobility through simulating upperclass aesthetic dispositions, but this person will be exposed by the incapability of assuming (embodying) the finer details of that higher-class habitus (Bourdieu 1979). Grounded in a similar popular understanding of social mobility and symbolic capital, many "vanguard revolutionaries" viewed sifrinos with a mix of pity and contempt. In embracing middle-class identity markers (sociolect, consumption symbols, talking in a denigrating manner about poor people and popular culture, using a scornful middleclass discourse about Chávez and the government, being "snobbish") they are performing an act of "class betrayal." Yet, they will never be able to "become middle-class" and be fully socially accepted by the middle class, no matter how hard they try. 


\section{Reappreciating the National-Popular}

As the text "What does it mean to be from Sambil Society?" illustrates, imageries and discourses of consumption tie up with the broader politicalcultural process of carving out a new sense of nationalism and national dignity. Central to this process is a rejection of the symbols of Western consumer capitalism and a revaluation of what is perceived as the "authentic" and "autochthonous" Venezuela.

The latter is, in popular and political discourses, often represented by national traditions and costumes like folkloric and popular music, Venezuelan traditional food (some stereotyped binaries: arepa instead of bread, pabellón criollo instead of McDonald's, papillón con limón instead of coke, hallaca instead of Christmas turkey), watching Venezuelan movies instead of the latest Hollywood blockbusters, going on vacation in Venezuela instead of going abroad, appreciating traditional folkloric dances and African drums rather than Western commercial music.

Rosa, a woman in her 60s from Propatria, recalled how it used to be "shameful" to listen to popular and folkloric music even in the barrios; it was considered backward and not fashionable. Instead of letting the music blast from open windows, as they usually did, they would listen to it behind closed doors. Whether this is true I don't know, but the fact that she recalls it this way illustrates how the "traditional Venezuela" was devaluated even in popular imagination.

\section{Counter-Cultures}

Fernandes (2010) argues that cultural identities in Venezuela under Chavez "provided an idiom for the expression of class and racial cleavages in an emerging battleground between multiple competing tendencies in Venezuelan society" (Fernandes 2010:114). In a similar vein I would suggest that the attempt to create a counter-culture to the global consumer culture by emphasizing traditional, popular and national symbols, values and commodities represents an idiom for articulating the broader culturalpolitical struggle that the Bolivarian process represented. Consumerismin its capacity of being global capitalism's seductive hoax and the prime signifier of bourgeois and elite identity—symbolizes the opposite of assuming a political consciousness and revolutionary agenda, thereby becoming a prime signifier within this ideological scheme.

However, one must be careful to interpret these dual schemes as contrasting and distinct "identity-imageries": one espousing Western moder- 
nity through consumption, and the other espousing anti-consumerist autochthonous, nationalist development. Rather, repertoires of meaning, cultural idioms and social formations shaping "consumer identities" in various guises in Venezuela are embedded in broader processes of identity formation and cultural-political symbolisms and ideologies. Members of different social and political groups are appropriating heterogeneous repertoires of goods and messages circulating within global circuits as well as in specific localities. Moreover, what constitutes "autochthonous Venezuelan culture" is evidently not a definite bundle of practices and tradition that is set in stone. In Venezuela, as in any other locality, what is espoused as an expression of "cultural authenticity" is malleable, vexing and open to both the invention and reinvention of tradition (Hobsbawm and Ranger 1992).

It is therefore important to underscore that rather than creating two binary "cultures" as if they were true reflections of binary identity constructs or "real" binary opposites, my intention here has been to illustrate how this schism is ideologically articulated within the dominant Bolivarian discourse. It reflects the political polarization in the country revolving around the construction of opposites: pro-government-opposition, pro-Venezuelapro-imperialism, pro-nation-pro-USA, pro-Socialism for the twenty-first century-pro-capitalism, pro-poor-pro-bourgeois. Within these opposites, "consumerism" emerged as a key symbolic marker expressing different cultural-political identities, imagined communities and moral economies.

This chapter started out with the observation of how "money" seemed to constitute a dense social signifier in Bolivarian discourse and social imaginaries, forming part of a broader narrative of a bundle of social vices that had been installed in society since long back. Consequently, I linked this to a theoretical and empirical exploration of how we may ground emic conceptualizations and social critique of "capitalism" and "neoliberalism" to the ways in which these macro-processes were imprinted in people's real lives. Furthermore, we discussed how stereotyped class and political identities were crafted around notions of cultural and material consumption drawing on distinctions between "autochthonous" culture and Western modernity. In Chap. 9, we will continue our exploration of contrasting, contradictory and symbol-laden notions of oil wealth and consumption. However, this time, our ethnographic focus is not conspicuous consumption, but the ways in which collective consumption through state distribution unfolded in the midst of the Bolivarian process. 


\section{Notes}

1. Though many die because they cannot afford to do it in proper clinics (see World Observer Online 2013).

2. Venezuelan children get their Christmas presents at midnight on the night of 24 December, and they are told that the presents are brought by the Jesus Child.

3. This is the date of the Chávez-led attempt to overthrow the Perez government; see Chap. 2.

4. Canaimita is a Venezuelan-assembled mini-computer that is handed out for free to children in public schools, produced based on an agreement with China.

5. The name itself caused a bit of controversy. Vergatario is a slang word for excellent, superb or optimal, but it is also a vulgar reference to penis.

6. This line deserves some explanation. On October 12, 2004, a statue of Christopher Columbus was torn down in Caracas in protest against the celebration of the discovery of the Americas. October 12 has previously been celebrated as a national holiday, named Día de la Raza (day of the races). In Venezuela, this day has been re-baptized as Dia de Resistencia Indígena (day of indigenous resistance). The destruction of the statue was heavily criticized by the opposition who termed it an act of Chávez's "hordes" and the Bolivarian Circles, who are commonly referred to as circles of terror in opposition media (see Chap. 5). On the other hand, Cacique Guacaipuro was an Indian tribal leader who led the resistance against the invasion of the Spaniards. His statue was brought down by opposition marchers during the guarimbas in 2004-guarimbas refers to street riots which were put in motion by the opposition with the purpose of inciting a civil uprising.

7. To bang pots and pans against each other is a common form of public protest in Latin America, predominantly among the middle classes.

\section{BIBLIOGRAPHY}

Appadurai, Arjun. 1988. The Social Life of Things. Commodities in Cultural Perspective. Cambridge: Cambridge University Press.

Apter, Andrew. 1993. "Festac for Black People": Oil Capitalism and the Spectacle of Culture in Nigeria. Paper delivered at the Presenting the Past Workshop, Northwestern University, Evanston, April 16.

Arnett, Peter. 1978. Oil Boom-Town. Conspicuous Consumption on a Grand Scale. The News and Courier, May 21. http://news.google.com/newspapers?n $\mathrm{id}=2506 \& \mathrm{dat}=19780521 \& \mathrm{id}=\mathrm{w} 51$ JAAAAIBAJ $\&$ sjid $=$ fgwNAAAAIBAJ \&pg $=1422,4549248$. Accessed January 2, 2014.

Bourdieu, Pierre. 1979. Distinctions. A Social Critique of the Judgment of Taste. Cambridge, MA: Harvard University Press. 
Chatterjee, Partha. 2004. The Politics of the Governed. Reflections on Popular Politics in Most of the World. New York: Colombia University Press.

Comaroff, Jean, and John L. Comaroff. 1987. The Madman and the Migrant: Work and Labor in the Historical Consciousness of a South African People. American Ethnologist 14 (2): 191-209.

- 1999. Occult Economies and the Violence of Abstraction: Notes from the South African Postcolony. American Ethnologist 26 (2): 279-303.

- 2001. Naturing the Nation: Aliens, Apocalypse and the Postcolonial State. Journal of Southern African Studies 27 (3): 627-651.

Coronil, Fernando. 1997. The Magical State: Nature, Money, and Modernity in Venezuela. Chicago: University of Chicago Press.

- 2008. Chávez's Venezuela. A New Magical State? In ReVista. Harvard Review of Latin America, vol. 8. Cambridge, MA: David Rockefeller Center for Latin American Studies, Harvard University.

Debord, Guy. 1967. The Society of the Spectacle. New York: Zone Books.

Douglas, Mary, and Baron Isherwood. 1996. The World of Goods. Towards an Anthropology of Consumption. London and New York: Routledge.

Englund, Harri, and James Leach. 2000. Ethnography and the Meta-Narrative of Modernity. Current Anthropology 41 (2): 225-248.

Ewell, Judith. 1984. Venezuela. A Century of Change. London: C. Hurst \& Company.

Fernandes, Sujatha. 2010. Who Can Stop the Drums? Urban Social Movements in Chávez’ Venezuela. Durham and London: Duke University Press.

Fourcade, Marion, and Kieran Healy. 2007. Moral Views on Market Society. Annual Review of Sociology 33: 285-311.

Friedman, Jonathan. 1994. Consumption and Identity. London and New York: Routledge.

Gledhill, John. 1995. Neoliberalism, Transnationalization and Rural Poverty: A Case Study of Michoacan, Mexico. Boulder: Westview Press.

- 2004. Neoliberalism. In A Companion to the Anthropology of Politics, ed. D. Nugent and J. Vincent. Malden, MA: Blackwell Publishing.

Graeber, David. 2011. Consumption. Current Anthropology 52 (4): 489-511.

Guevara, Ernesto Che. 2003 [1965]. Socialism and Man in Cuba. In Che Guevara Reader. Writings on Politics and Revolution, ed. D. Deutchman. Melbourne and New York: Ocean Press.

Harvey, David. 2005. A Brief History of Neoliberalism. Oxford: Oxford University Press.

Hillman, Richard. 1994. Democracy for the Privileged. Crisis and Transition in Venezuela. Boulder and London: Lynne Rienner Publishers.

Hobsbawm, Eric, and Terence O. Ranger. 1992. The Invention of Tradition. Cambridge: Cambridge University Press.

Hoffman, Kelly, and Miguel Angel Centeno. 2003. The Lopsided Continent: Inequality in Latin America. Annual Review of Sociology 29: 363-390. 
Howell, Signe. 1997. Introduction. In The Ethnography of Moralities, ed. S. Howell. London and New York: Routledge.

Informe21. 2013. Venezuela: El consumismo versus socialismo del siglo XXI. http:// informe21.com/elecciones-presidenciales/venezuela-el-consumismo-versussocialismo-del-siglo-xxi. Accessed February 20, 2017.

Jackson, Peter. 1999. Commodity Cultures: The Traffic in Things. Transactions of the Institute of British Geographers 24 (1): 95-108.

- 2004. Local Consumption Cultures in a Globalizing World. Transactions of the Institute of British Geographers 29 (2): 165-178.

Karl, Terry Lynn. 1997. The Paradox of Plenty. Oil Booms and Petro-States. Berkeley: University of California Press.

- 1999. The Perils of the Petro-State: Reflections on the Paradox of Plenty. Journal of International Affairs 53 (1): 31-48.

Lander, Edgardo. 2005. Venezuelan Social Conflict in a Global Context. Latin American Perspectives 32 (2): 20-38.

McGregor, Sue. 2002. Consumer Citizenship: A Pathway to Sustainable Development? Keynote speech delivered at the International Conference on Developing Consumer Citizenship, Hamar, Norway, April n.d. http://www.consultmcgregor. com/documents/keynotes/norway_keynote.pdf. Accessed February 20, 2017.

Miles, Steven. 1998. Consumerism as a Way of Life. London: Sage.

Mullins, Paul R. 2011. The Archaeology of Consumer Culture. Gainesville: University Press of Florida.

Notiactual. 2011. Todos los centros Sambil de Venezuela celebrarán bodas colectivas el próximo 14 de febrero. Notiactual, January 13. http://www.notiactual. com/todos-los-centros-sambil-de-venezuela-celebraran-bodas-colectivas-elproximo-14-de-febrero/. Accessed February 20, 2017.

Nugent, David. 1996. From Devil Pacts to Drug Deals: Commerce, Unnatural Accumulation, and Moral Community in "Modern" Peru. American Ethnologist 23 (2): 258-290.

Ortner, Sherry B. 2016. Dark Anthropology and Its Others. HAU: Journal of Ethnographic Theory 6 (1): 47-73.

Sætre, Simen. 2009. Petromania. Oslo: J.M. Stenersens Forlag AS.

Salas, Miguel Tinker. 2009. The Enduring Legacy. Oil, Culture, and Society in Venezuela. Durham and London: Duke University Press.

Sambil. 2017. http://tusambil.com

Sandel, Michael. 1998. What Money Can't Buy: The Moral Limits of the Market. Speech delivered at the Tanner Lectures on Human Values, Brasenose College, Oxford, May 11-12.

Silva, Emilio. 2005. Qué es ser de la Sociedad Sambil? Aporrea, June 2. http:// www.aporrea.org/actualidad/al3751.html. Accessed February 20, 2017.

Slater, Don. 1997. Consumer Culture and Modernity. Cambridge: Polity Press.

Taussig, Michael. 1977. The Genesis of Capitalism amongst a South American Peasantry: Devil's Labor and the Baptism of Money. Comparative Studies in Society and History 19 (2): 130-155. 
1980. The Devil and Commodity Fetishism in Latin America. Chapel Hill: The University of North Carolina Press.

Walsh, Andrew. 2003. "Hot Money" and Daring Consumption in a Northern Malagasy Sapphire-Mining Town. American Ethnologist 30 (2): 290-305.

Watts, Michael. 1999. Petro-Violence: Some Thoughts on Community, Extraction, and Political Ecology. Working Paper 99-1, Institute of International Studies, University of California, Berkeley.

- 2004. Anatomies of Community: Some Thoughts on Geography, Resources and Empire. Transactions of the Institute of British Geographers 29 (2): 195-216.

Weyland, Kurt. 2004. Neoliberalism and Democracy in Latin America: A Mixed Record. Latin American Politics and Society 46 (1): 135-157.

World Observer Online. 2013. 'It Hurts So Much I Can't Sit Down': The Dangerous Practice of Butt Implants That Is Ruining Women's Lives across Venezuela. World Observer Online, November 16. http://worldobserveronline. com/2013/11/16/hurts-much-cant-sit-dangerous-practice-butt-implantsruining-womens-lives-across-venezuela/. Accessed February 20, 2017.

\section{Audiovisuals}

1980. The Gods Must Be Crazy. Dir. Jamie Uys. South Africa: CAT Films/Mimosa Films.

2007. The People and the President. A Portrait of the Bolivarian Revolution. Dir. Iselin Strønen and Hildegunn Wrrness. Bergen, Norway: Geriljastil Productions.

Open Access This chapter is distributed under the terms of the Creative Commons Attribution 4.0 International License (http://creativecommons.org/ licenses/by $/ 4.0 /$ ), which permits use, duplication, adaptation, distribution and reproduction in any medium or format, as long as you give appropriate credit to the original author(s) and the source, provide a link to the Creative Commons license and indicate if changes were made.

The images or other third party material in this chapter are included in the chapter's Creative Commons license, unless indicated otherwise in a credit line to the material. If material is not included in the chapter's Creative Commons license and your intended use is not permitted by statutory regulation or exceeds the permitted use, you will need to obtain permission directly from the copyright holder.

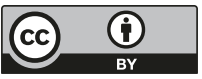

